\title{
Editorial
}

\section{Merawat Hak Asasi Manusia}

Kita semua mahfum, sejarah hak asasi manusia (HAM), terutama kemunculan instrumen-instrumen HAM selalu dilatarbelakangi oleh kulminasi berbagai pelanggaran HAM. Absolutisme monarki Inggris di masa lalu berangsur-angsur melahirkan satu demi satu instrumen HAM, mulai dari Magna Charta (1215) yang sifatnya sangat elitis hingga Bill of Rights 1689 yang dianggap sebagai kemenangan rakyat (Jimly Asshidiqie: 2006, hlm. 87). Demikian pula pada level internasional, solidaritas penghapusan perbudakan pada abad 18-19, melahirkan kelembagaan dan berbagai dokumen HAM yang tak selalu mulus, mulai dari Liga Bangsa-Bangsa, International Labour Organization (ILO) dan berbagai konvensi internasional-nya hingga kehadiran Perserikatan Bangsa-Bangsa (PBB) dan the International Bill of Rights: UDHR, ICCPR, dan ICESCR (Rhona K.M. Smith, et.al.: 2008, hlm. 32-36).

Perkembangan HAM baik jaminan maupun implementasinya sangat dinamis, dan bergantung pada konteks sosial politik masyarakat, baik pada tingkat nasional maupun internasional. Bahkan ada yang mengatakan bahwa HAM tidak dapat didekati oleh teori yang bersifat idealistik seperti teori keadilan John Rawl, namun teori HAM merupakan teori non-ideal karena berupaya untuk memahami "bagaimana bergerak dari konstruksi ketidakadilan ke konstruksi yang lebih adil, bukan hanya menteoritisasi tentang bentuk dari konstruksi keadilan" (Brooke A. Ackerly: 2008, hlm. 43). Dengan demikian, isu HAM bukan hanya persoalan 'jaminan' namun juga mekanisme, implementasi, dan perilaku negara dan masyarakat. Dengan kata lain, upaya merawat HAM dalam praktik sama pentingnya dengan menjamin HAM secara normatif.

Masyarakat Indonesia sendiri kembali menikmati jaminan HAM yang komprehensif sejak Reformasi 1998. Jaminan HAM begitu menguat terutama sejak Perubahan Kedua UUD 1945 pada tahun 2000 mengatur bab khusus tentang HAM (Bab XA). Jaminan HAM yang begitu komprehensif dalam UUD 1945 menjadikannya sebagai hak yang dilindungi secara konstitusional (constitutional rights) yang diharapkan dapat memperkuat pemajuan dan perlindungan HAM di Indonesia (Bagir Manan dkk, 2001: hlm. 83-84). Daftar instrumen HAM internasional yang diratifikasi Indonesia pun semakin bertambah panjang. Dua Instrumen HAM internasional utama, yakni ICCPR dan ICESCR menjadi bagian dari hukum nasional Indonesia setelah diratifikasi pada tahun 2005. Namun, apakah premis the full realization of human rights betul-betul sudah terwujud? Tentu saja belum. Jika kita sepakat menempatkan persoalan HAM sebagai sebagai suatu hal yang tidak netral: final secara normatif, kondisional secara praktikal, maka selalu ada pasang surut realisasi HAM, baik oleh negara sebagai pengemban kewajiban, maupun implementasi oleh rakyat sebagai pemangku hak. 
Kondisi Indonesia pasca Reformasi 1998 dengan jaminan hak-hak politik yang komprehensif, memunculkan antitesa: rakyat kuat, negara lemah. Bahkan, di samping realisasi hak politik yang menguat, seperti kebebasan pers, kebebasan berpendapat dan berorganisasi, ada pula efek samping dari hak-hak kebebasan yang disalahgunakan, seperti perilaku anarkis, merusak dan sebagainya. Namun demikian, ketika persepsi masyarakat terhadap HAM mulai menunjukkan kedewasaan berpikir, dan institusionalisasi HAM dalam prosedur bernegara mulai terbangun, ada pula kecenderungan penyangkalan HAM oleh negara. Kasus terkini penyangkalan hak atas air petani Kendeng sebagai derivasi hak atas hidup mereka, dapat menunjukkan kecenderungan ini. Ada kekhawatiran, ketika negara mulai kembali fokus membangun infrastruktur fisik, pendekatan teknokratisme mulai kembali menjadi arus utama, dan pendekatan HAM mulai ditinggalkan.

Dunia akademik, khususnya dunia keilmuan hukum, perlu merespon kecenderungan demikian. Upaya merawat HAM bagi academia hukum, juga harus ditunjukkan tentu melalui jalur-jalur akademik, seperti riset, tanpa menyangkal pentingnya advokasi sebagai bentuk pengabdian kepada masyarakat. Namun perlu dicatat, secara umum studi HAM lebih didominasi ilmu hukum, ketimbang ilmu sosial terutama melalui pendekatan normatif (Freeman, 2001 dalam Tod Landman: 2006, hlm. 1). Di sisi lain, konteks HAM yang dinamis menuntut analisis terhadap realisasi dan implementasi HAM secara praktikal, selain studi normatif. Studi demikian menjadi penting untuk menganalisis berbagai faktor non-ideal yang menghambat atau faktor yang mendorong keberhasilan realisasi HAM. Oleh karena itu, pendekatan studi empirikal seperti sosiolegal terhadap HAM dianggap sebagai upaya melengkapi berbagai studi HAM yang sudah ada (Patrick Schmidt \& Simon Halliday: 2004, hlm. 3). Tradisi riset demikian diharapkan juga mulai terbangun oleh para peneliti HAM di Indonesia terutama yang berlatar belakang ilmu hukum.

Upaya mengidentifikasi faktor-faktor empiris penegakan HAM menjadi penting untuk mengetahui posisi saat ini: apa yang sudah dicapai dan sejauh mana serta apa yang belum dicapai. Seperti halnya hukum yang non-self executing, norma-norma HAM pun tidak berjalan dengan sendirinya. Memahami persoalan realisasi HAM melalui riset empiris- dapat membantu upaya mendesain mekanisme HAM dalam kenyataan yang lebih efektif. Namun, mengingat penguasaan metode riset empiris, tidak secara spesifik menjadi kemampuan para akademisi hukum, maka upaya riset kolaboratif antara lawyers dan ilmuwan sosial perlu didorong. Riset-riset ini diharapkan dapat menjembatani gap antara norma-norma HAM yang bersifat idealistik dengan persoalan penegakan HAM dalam kenyataan. Dengan kata lain, merawat HAM dalam kenyataan adalah suatu keharusan, namun hanya dapat dilakukan jika persoalan HAM dapat dipahami bukan hanya secara normatif, namun juga secara praktikal. 
Dalam rangka Hari HAM Internasional 10 Desember, terdapat 6 artikel bertema HAM dalam edisi ini. Diawali pada kolom Artikel Kehormatan, Prof. Bagir Manan dan Susi Dwi Harijanti menulis persoalan Konstitusi dan HAM. Tulisan selanjutnya, Abdul Haris Semendawai membahas penetapan Status Justice Collaborator bagi tersangka atau terdakwa dalam Perspektif HAM. Dari perspektif hukum HAM internasional, Diajeng Wulan Christianti menganalisis persoalan kejahatan penyelundupan manusia dan perlindungan pencari suaka untuk kasus pengungsi Rohingnya. Artikel keempat, Ali Abdurahman dan Mei Susanto menekankan kembali pembentukan Undang-Undang Komisi Kebenaran dan Rekonsiliasi di Indonesia yang sebelumnya pernah dibatalkan oleh Mahkamah Konstitusi. Selanjutnya dan satu-satunya artikel berbahasa Inggris pada edisi kali ini, Nabilla Utami Dhiya Rahmani menganalisis implikasi hukum deklarasi Palestina dan aksesi terhadap Statuta Roma dalam kasus serangan Israel ke Gaza (2009-2014). Terakhir dan satu-satunya pula artikel yang tidak hanya membahas HAM dari aspek normatif, ditulis oleh Trini Handayani mengenai optimalisasi pola asuh Maternalistik dalam pencegahan kejadian paedofilia. Kemudian 4 artikel lainnya yang mengangkat isu di luar tema HAM dari Mardianis, Kama Sukarno, Purnama Trisnamansyah, dan Siti Hapsah Isfardiyana, tidak kalah menarik untuk dibaca.

Selain itu, rubrik book review dan khazanah tetap menjadi ciri khas setiap edisi. Book review kali ini ditulis oleh Irawati Handayani terhadap buku berjudul Jus Cogens - International Law and Social Contract. Kemudian pada rubrik Khazanah masih melanjutkan paham positivisme hukum dari edisi lalu, kali ini membahas pemikiran Hart. Selamat membaca! 